\title{
DOI https://doi.org/10.30525/978-9934-26-041-4-81
}

\section{ВИКОРИСТАННЯ ІГРОВИХ ПЕДАГОГІЧНИХ ТЕХНОЛОГІЙ НА ЗАНЯТТЯХ МИСТЕЦТВА}

\author{
Ткемаладзе 3. П. \\ викладач-методист \\ кафедри музично-інструментальної підготовки вчителя \\ Комунальний заклад «Харківська гуманітарно-педагогічна академія» \\ Харківської обласної ради \\ Золотарьова О. I. \\ старший викладач-методист \\ кафедри музично-інструментальної підготовки вчителя \\ Комунальний заклад «Харківська гуманітарно-педагогічна академія» \\ Харківської обласної ради \\ м. Харків, Украӥна
}

На сучасному етапі розвитку педагогіки організація занять музичного мистецтва потребує використання різних художньо-педагогічних технологій. Гра - найбільш вільна діяльність людини й завжди бажана та цікава. Вона не існує без задоволення й наснаги, несе 3 собою енергетичний підйом, веселий настрій, захоплення й натхнення. В ігровій формі можна проводити як окремі етапи уроку музичного мистецтва, так i весь урок. До кожної теми уроку, окремого виду діяльності можна придумати гру. Для iї створення потрібні винахідливість і фантазія. Завдання гри - сприяти активному розвитку музичних здібностей, засвоєнню теоретичного матеріалу. Вона має викликати сильні й тривалі позитивні емоції, бажання навчатися без примусу.

Гра - це не імітація життя, а саме життя. Це насамперед творча дія, яка розгортається немовби не в реальному просторі, а у світі символічних значень, живої фантазії. Природа гри синкретична i міфологічна, що відповідає характеру мислення дитини, яка сприймає світ цілісно, не розділяючи реальне і «придумане» непробивними мурами. Ігри виробляють в учнів «рефлекс свободи», адже рішення приймається самостійно. На заняттях імітаційно-ігрового типу діти вчаться через стосунки, контакти, тому в них формуються почуття співпричетності й співпереживання. Так гра стає справжньою школою соціального досвіду, соціалізації [1].

Важливим фактором естетичного розвитку і саморозвитку дитини стає художньо-ігрове моделювання змісту інтегрованих уроків, що 
передбачає використання різних ігрових форм: театралізованих (пантоміміка, імітаційні лялькові діалоги, розгорнуті драматизації, інсценізації), хореграфічних (пластичне інтонування, танцювальні пісні-ігри, хореографічні фантазії). Такі методи і прийоми збагачують i доповнюють композицію інтегрованого уроку, і якщо його сценарій розроблено з відповідною методичною доцільністю, вони створюють ситуації, коли вчитель може активізувати учнів згідно з їхніми художніми здібностями й можливостями.

Гра - це модель певного реального процесу, імітація, відтворення в умовних обставинах певних життєвих ситуацій. Структура гри передбачає наявність об'єкта ігрового моделювання, загальної мети; підготовчий етап; розподіл класу на групи, ролей між учасниками гри; взаємодія учасників гри; підбиття підсумку, індивідуальна, групова, колективна оцінка діяльності (самооцінка), з'ясовується, що не вдалося зробити і чому.

Дітей молодшого шкільного віку відрізняє велика рухова активність, підвищений емоційний стан, бажання фантазувати. Ці риси знаходять своє позитивне втілення в ігровій діяльності, яка поєднує трудову, навчальну, ігрову та комунікативну складові. Під час організації гри треба враховувати тривалість гри; залучення всіх дітей класу (можна й батьків); розподіл функцій, ролей.

3 раннього дитинства в різноманітній ігровій діяльності через механізм наслідування різних граней життя дорослих відбувається особистісне становлення маленької дитини. Вона набуває мовленнєвий i комунікативний досвід, засвоює практичні, зокрема трудові та художні навички. Ігрове начало пронизує життєдіяльність і дорослої людини, хоча вже і не домінує, як у дитинстві. Людина продовжує «грати», тільки в інших формах. Гра корисна тим, що допомагає людині керувати своїми емоціями, долати сенсорний та емоційний голод, засвоювати різноманітні форми людської взаємодій. Виконання різних «соціальних ролей» у перебігу гри завжди невимушене. Наприклад, під час обрядів, свят, ритуалів, насичених ігровими діями, від старшого до молодшого покоління передаються етнокультурні традиції. I такий шлях дієвого успадкування національних традицій набагато ефективніший, ніж просто прочитати про них або дізнатися з радіо чи телепередачі.

Потреба в грі не згасає й тоді, коли діти приходять до школи й починають опановувати новий вид діяльності - навчальний. За рахунок гри розширюються горизонти власного естетичного досвіду. На уроках мистецтва на емоційно забарвлених, значущих для дитини художньоігрових моделях молодші школярі вчаться розуміти мову почуттів, жестів, рухів, а поступово і більш складних феноменів - інтонацій, знаків, символів. Важлива роль мистецтва в тому, що його можна розглядати як художньо-пізнавальну модель дійсності, своєрідну «гру в життя». 
Сучасна педагогіка шукає ефективні засоби дидактичного поєднання гри і театрального мистецтва. Театральна гра, яка синтезує розвиваючий потенціал ігрової та мистецької діяльності, відіграє нічим не заміниму роль у розвитку пізнавальних і творчих здібностей дітей.

Через сюжетно-рольову гру, що передбачає обов'язкове перевтілення, учні мають можливість ідентифікувати себе з будь-яким героєм, «приміряти на себе» різні характери, манери поведінки, пережити безліч ситуацій і вчинків. Це збагачує не лише естетичний досвід, а робить особистість у цілому більш гармонійною, духовно досконалішою загалом. Ігрова діяльність також дає змогу уявити себе в надзвичайних, фантастичних обставинах, «програти» неймовірні ситуації. Така ілюзорність вимагає творчих дій - умінь комбінувати, моделювати, уточняти або змінювати деталі. Так переплітаються найважливіші функції гри - евристична і соціалізаційна.

У педагогічній літературі ігри розподіляються на дві великі групи: ігри за правилами, що мають фіксований зміст, та ігри творчі, вільні.

До першої групи належать дидактичні, інтелектуальні, пізнавальні ігри. Як і будь-якій грі, їм притаманні елементи розваг (загадки, ребуси, кросворди, лото, вікторини, а також умовні подорожі та круїзи, конкурси, ярмарки, аукціони). Різновидом ігор з правилами є рухливі (спортивні, хороводні): естафети, турніри, атракціони тощо.

До другої групи входять художньо-конструкторські (з елементами праці) i сюжетно-рольові ігри (ігри-драматизації, інсценізації, театралізовані ігри).

Особливий статус мають народні ігри, які з огляду на їх потужний естетико-виховний потенціал доцільно активно застосовувати у школі, починаючи з молодших класів.

На уроках мистецтва можуть знайте своє місце всі наведені види ігор, проте найдоцільнішими, безумовно, будуть ті, що безпосередньо випливають із завдань художнього розвитку школярів. Добираючи рухливі ігри до занять мистецтва, вчитель має віддавати пріоритет не спортивним, а музично-хореографічним їх видам.

У традиційних класних приміщеннях відсутні умови, потрібні для організації повноцінної танцювальної діяльності учнів, тому в перебіг занять мистецтва краще включати форми хореографічних мініатюр, які обмежуються нескладними рухами і не вимагають спеціального сценічного простору. Це і традиційне для занять музичного мистецтва пластичне інтонування, що нерідко супроводжує виконання пісні, i танцювальні рухи при сприйманні відповідних творів танцювального характеру. Театральний компонент шкільної мистецької освіти може здійснюватися за допомогою різних форм і методів від простої сюжетно-рольової гри до створення дитячого театру класу або школи i 
проведення уроків-вистав. До форм і методів театральної педагогіки, до навчально-виховного процесу в початковій школі можна включати такі, як драматизація, пантоміма, інсценізація, театралізація.

На заняттях музичного мистецтва система художньо-творчих завдань насичена ігровими елементами. Замість нот на нотному стані 3'являються квіточки й дзвоники 3 лінії на лінію нотоносця «перелітають» пташки або метелики (вони показують, як мелодія рухається вгору або вниз). Учням цікаво прочитати слова, в яких «сховалися» нотки: дорога, дощик, дошка, довкілля, море, дерево, вітерець, ремінь, пюре, камінь, посмішка, промінь, ведмідь, фарби, шафа, фари, парасолька, лялька, квасоля, теля, земля, таксі, сіль, сік, або навіть дві - помідор, доміно. Через механізм гри («Уяви себе композитором») діти без традиційного остраху перед складністю музично-творчої діяльності виконують такі завдання: проплескати або заграти на дитячих інструментах ритмічні партитури; зімпровізувати інтонації комічних і фантастичних персонажів, завершити розспівку, створити образи-мелодії казкових героїв [2].

Великий діапазон театралізованих ігрових завдань на основі пантоміми для молодших школярів просто необмежений. За допомогою міміки, жестів, рухів учні здатні «оживити» картину або скульптуру, розіграти під впливом художніх образів сценку, діалог.

Ігрові художньо-педагогічні технології урізноманітнюють і доповнюють композицію уроку мистецтва, підвищують його ефективність, якщо вони розроблені з дидактичною та виховною доцільністю і впроваджені з методичною майстерністю.

Таким чином ігрові педагогічні технології активізують пізнавальну діяльність учнів, розвивають художньо-образне мислення; збагачують почуттєву сферу дітей, посилюють емоційність сприйняття художньодидактичного матеріалу, загальну мотивацію навчання; стимулюють розвиток творчих здібностей, уяви, фантазії; формують елементи художньо-естетичного і соціокультурного досвіду; сприяють релаксації, здійснюють емоційну саморегуляцію, забезпечують профілактику психічної втоми, подолання гіподинамії.

\section{Література:}

1. Дичковська І. Інноваційні педагогічні технології. Київ, 2004. 352 с.

2. Рудницька Л. Педагогіка: загальна та мистецька. Київ, 2002. 270 с.

3. Сучасний урок. Інтерактивні технології навчання / Наук.-метод. посібник Пометун О., Пироженко І./ Київ, 2004. 192 с. 